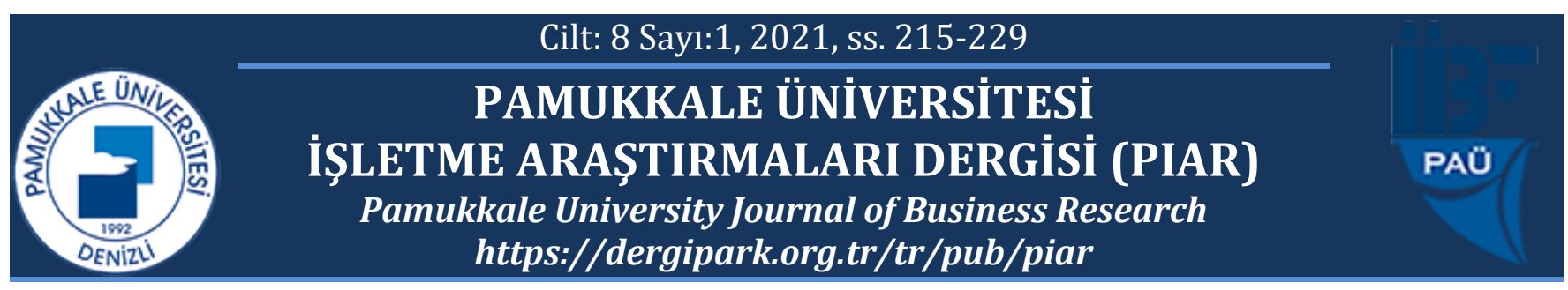

\title{
İşyeri Mutluluğunun Öncülleri ve Sonuçları Üzerine Nitel Bir Çalışma
}

\author{
A Qualitative Study on the Antecedents and Consequences of Workplace \\ Happiness
}

\section{Beyza ERER ${ }^{*}$}

\author{
${ }^{1}$ Selçuk Üniversitesi Sosyal Bilimler MYO, beyzaerer@selcuk.edu.tr, https://orcid.org/0000-0003-0083-7102 \\ * Yazışılan Yazar/Corresponding author
}

\section{Öz}

İşyeri mutluluğu, örgütlerin geleceği ve bireylerin genel hayat mutluluğu açısından son derece önemli bir konudur. Bu yönüyle iş yaşamında çalışanları mutsuz eden unsurlar belirleyip düzeltmekle birlikte onları gerçekte nelerin mutlu ettiğini keşfetmek ve mutlu çalışanların tutumların belirlemek de örgütlerin başarısı açısından önemli bir husustur. Bu bağlamda çalışmanın amacı, özel sektör çalışanlarının deneyimlerinden faydalanarak işyeri mutluluğunun öncüllerini ve sonuçlarmı belirlemektir. Çalışmada nitel araştırma desenlerinden fenomenoloji yaklaşımı kullanılmıştır. Araştırmanın katılımcıları amaçl örneklem yöntemine göre seçilen 10 kişiden oluşmaktadır. Araştırma verileri açık uçlu sorulardan oluşan yarı yapılandırılmış görüşme formu kullanılarak toplanmış olup ayrıca görüşme strasında katılımcıların vermiş oldukları cevaplara yönelik sondaj sorular da sorulmuştur. Verilerin analizinde ise içerik analizi kullanılmıştır. Araştırmadan elde edilen verilere göre, işyeri mutluluğunun öncülleri; "bireysel faktörler, yönetici kaynakl faktörler, örgütsel faktörler, iş ile ilgili faktörler ve çevresel faktörler" şeklinde belirginlik kazanmıştır. Işyeri mutluluğunun sonuçlarn ise; "örgütsel sonuçlar" ve "bireysel sonuçlar" olmak üzere iki tema altında sinıflandırılmıştır. Nitel araştırma yöntemi sayesinde işyeri mutluluğuna ait öncüllerin ve sonuçların detaylı bir şekilde değerlendirilmesini sağlayan bu araştırma sonuçlarının ileride yapılması planlanan çalışmalar için yaralı olacağı düşünülmektedir.

Anahtar kelimeler: Mutluluk, İsyeri Mutluluğu, Nitel Araştırma Yöntemi, Fenomenoloji, Pozitif Örgütsel Davranış

JEL kodlart: D23, C10

\begin{abstract}
Workplace happiness is an extremely important issue in terms of the future of organizations and the general happiness of individuals. In this respect, identifying and correcting the factors that make employees unhappy in business life, discovering what actually makes them happy and determining the attitudes of happy employees is also an important issue for the success of organizations. In this context, the purpose of this study is to determine the antecedents and results of workplace happiness by making use of the experiences of private sector employees. The phenomenology approach, one of the qualitative research designs, was used in the study. The participants of the study consist of 10 people selected according to the purposeful sampling method. The research data were collected using a semi-structured interview form consisting of open-ended questions, and also probe questions were asked about the answers given by the participants during the interview. Content analysis was used in the analysis of the data. According to the data obtained from the research, the antecedents of workplace happiness are; It became prominent as "individual factors, manager-based factors, organizational factors, business-related factors and environmental factors". The results of workplace happiness are; It has been classified under two themes as "organizational results" and "individual results". It is thought that the results of this research, which provides a detailed evaluation of the antecedents and results of workplace happiness thanks to the qualitative research method, will be useful for future studies.
\end{abstract}

Keywords: Happiness, Workplace Happiness, Qualitative Research Method, Phenomenology, Positive Organizational Behavior.

JEL codes: D23, C10 


\section{GİRIŞ}

Son yıllarda pozitif psikolojiye ait değişkenlerin örgütsel davranış, örgütsel psikoloji ve çalışma psikolojisi alanlarında yapılan çalışmalarda sıklıkla kullanıldığı görülmektedir. Bu değişkenlerden biri de, bireyin pozitif duygu durumunun yansıması şeklinde ortaya çıkan "mutluluk" kavramıdır. Bu kavramın çalışma hayatındaki karşılığı ise işyeri mutluluğu, örgütsel mutluluk, çalışan mutluluğu, çalışma mutluluğu, iş mutluluğu veya işte mutluluk şeklinde ortaya çıkmakta ve her biri de aynı anlamda kullanılmaktadır.

Uyku harici günün büyük bir bölümünü çalışarak geçiren bireylerin mutlulukları için "işyeri" önemli bir kaynak teşkil etmektedir. Bireylerin, hayatlarının en verimli ve en uzun dönemlerini geçirdikleri işyerlerine her gün isteyerek ve severek gitmesi, işlerini en iyi şekilde ve zamanında bitirmesi için işyerinde mutlu olmaları gerekir. Dolayısıyla işyeri mutluluğu hem bireyler hem de örgütler açısından önemlidir. Bu yönüyle işyeri mutluluğu bireysel açıdan ele alındığında bireyin yaşam kalitesine olumlu katkı sağlaması yönünden önemli iken örgütsel açıdan ise bireyin işte mutlu olması iş performansı, motivasyonu ve verimliliği yönünden pozitif sonuçları ifade ettiğinden dolayı önemlidir (Keser, 2018: 48). Böylesi önemli bir fenomenin son yıllarda sıklıkla gündemde olmasına rağmen üzerinde yeteri kadar akademik çalışma yapılmaması bu çalışmanın çıkış noktasını oluşturmaktadır. Özellikle ulusal literatürde yapılan çalışmaların daha çok işyeri mutluluğuna ait kavramsal çerçevenin veya kuramsal yapının oluşturulmasına yönelik olduğu belirlenmiş ve görgül araştırmaların sınırlı sayıda olduğu gözlenmiştir. Bu nedenle bu araştırmanın amacı, oluşumunda birden çok değişkenin etkili olduğu düşünülen işyeri mutluluğunun öncüllerini ve sonuçlarını nitel araştırma yöntemi ile kapsamlı bir şekilde ortaya koymaktır. Araştırma kapsamında elde edilen verilerin yazına katkı sağlayacağı düşünülmektedir.

\section{2. İŞYERİ MUTLULUĞU}

Bireyler için mutluluk, yaşamdaki en temel amaçlardan biridir (Gilman vd., 2000: 135). Çünkü yapılan araştırmalarda, çoğu insanın en çok arzuladıkları şeyin mutluluk olduğu sonucuna ulaşılmıştır (Diener, 2000: 34). Mutluluk, bireyin herhangi bir anda deneyimlemiş olduğu güzel ruh halini ve sezgilerini ifade eden olumlu bir duygulanma, yaşamın iyi olarak değerlendirilmesi veya öznel iyi oluş olarak tanımlanmaktadır (Deiner ve Ryan, 2009: 391). Veenhoven (2009: 45)'e göre mutluluk; insanın yaşamış olduğu hayatı ne kadar fazla sevdiği ya da hayatını bir bütün olarak olumlu değerlendirme derecesidir. Bu tanımdaki temel unsur, yaşamın "öznel değerlendirilmesi" veya "beğenilmesi" olup aynı zamanda yaşam "tatmini" şeklinde de ifade edilmektedir. Türkçe Sözlükte mutluluk, "bütün özlemlere eksiksiz ve sürekli olarak ulaşılmaktan duyulan kıvanç durumu, mut, ongunluk, kut, saadet, bahtiyarlık, saadetlilik" olarak açılanmaktadır (TDK, 2011). Yapılan tanımlamalar dikkate alındığında, mutluluğa yönelik tek bir tanımın yapılmadığı dikkat çekmektedir. Bu yönüyle mutluluğun doğası gereği öznel bir kavram olduğu ve genel olarak yaşamdan duyulan hoşnutluğu ifade ettiği söylenebilir.

Mutluluk yalnızca bireylerin özel yaşamlarında değil iş yaşamlarında da ortaya çıkan ve üzerinde önemle durulması gereken konular arasında yer almaktadır. Çünkü bireyin tam kapasite ve yüksek performansla çalışabilmesi işyerinde mutlu olmasına bağlıdır (Akın ve Aktar, 2019: 6). Bu bağlamda işyeri mutluluğu, bireylerin işyerinde algıladıkları olumlu duyguların olumsuz duygulardan daha fazla olması durumudur (Brief ve Weiss, 2002; akt. 
Arslan ve Polat, 2017: 613). Maenapothi'ye (2007) göre, işyerinde mutluluk, çalışanların çalışmaktan mutlu olduğu ve kendilerini çalışıyormuş gibi hissetmediği, verimli olduğu ve hem çalışan düzeyinde hem de kurumsal düzeyde planlanan hedeflere ulaştığı iş yeri durumudur. Pryce-Jones (2010: 1) işyeri mutluluğunu, bireyin performansını maksimum seviyeye çıkarmasına ve potansiyeline ulaşmasına olanak sağlayan düşünce yapısı olarak tanımlamakta ve işte mutluluk ile ilgili üç önemli hususa vurgu yapmaktadır. Söz konusu hususların ilki, çalışanın kendi yaklaşımı ve farkındalığı; ikincisi işteki mutluluğun sadece bireysel değil grup içi rollerle ilgili olduğu; üçüncüsü ise rahatsızlık ve zorluğun her türlü ilerlemede sürecin bir parçası olduğunu kabullenmektir. Turan (2018: 187) ise işyeri mutluluğunu; "bireyin yapmış/sahip olduğu işten tatmin ve memnun olması, çalıştığ1 kuruma karşı pozitif yaklaşım benimsemesi ve çalıştığı ortamda iyi ilişkiler geliştirmesine bağlı olarak gönüllü bir şekilde olumlu tutum ve davranış sergileyebilme hissi" olarak tanımlamaktadır.

Fisher (2010: 385-386) işyeri mutluluğunu; geçici mutluluk, bireysel düzeyde mutluluk ve birim düzeyinde mutluluk olmak üzere üç boyutta ele almıştır. Geçici işyeri mutluluğu, çalışma ortamında kişi bazında değişen ve kısa süreli yaşanan olumlu ruh hali, iş tatmini, akış deneyimi, işten zevk alma, memnuniyet ve içsel motivasyon gibi belirli duyguları içermekte ve "Neden bir çalışan bazen diğerinden daha iyi bir ruh hali içinde olur?", "Neden bir çalışan bazen akış durumu yaşarken bazen de yaşamaz?" ve "Bireyler, işte her zamankinden daha olumlu bir etki yaşadıkları günlerden sonra daha iyi uyuyor mu?" sorularına cevap aramaktadır. İşyerlerindeki mutluluk yapılarının çoğunun bireysel düzeyde gerçekleştiğini ve örgütsel davranış araştırmalarının bu düzeye yoğunlaştığını ifade eden yazar, bireysel düzeydeki mutluluk ile ilgili yapıların iş tatmini, duygusal bağlılık, işe katılım, gelişme ve canlılık gibi duyguları kapsadığını belirtmektedir. Ayrıca "İşyerinde neden bazı insanlar diğerlerinden daha mutlu veya daha mutsuz?" sorusunu bireysel düzeydeki işte mutluluğa örnek vermektedir. Birim düzeyindeki işyeri mutluluğuyla ilgili yapılar ise takım, departman ya da örgüt düzeyindeki mutluluk algısıdır. Grup iş/görev tatmini, grup ruh hali ve birim düzeyinde etkileşim birim düzeyindeki mutluluk yapılarına örnek olup, "Birim düzeyinde katılımın birim düzeyinde müşteri memnuniyeti üzerindeki etkileri nelerdir?" ve "Ekip ruh halinin bireysel ruh hali ve performans üzerindeki etkisi nedir?" sorularına cevap aramaktadır.

Kişisel motivasyon, yaş, işte özerklik ve sağlık durumu (Tadic vd., 2013), cinsiyet, eğitim seviyesi, gelir ve çocuk sayısı (Mahadea ve Ramroop, 2015), işyerindeki dikey ve yatay ilişkiler, örgüt büyüklüğü ve cinsiyet (Andrew, 2011), yöneticinin veya liderin tutumu, örgüt kültürü, işin özellikleri, çalışma ortamı (Williams vd., 2017), bireyin yaptığı işten keyif alması, işiyle gurur duyması, sürekli öğrenme ve gelişme isteği (Kjerulf, 2015), işte profesyonellik ve yetkinlik (Huag, 2016) işyeri mutluluğunu etkileyen faktörler arasında yer almaktadır. Söz konusu birçok faktörden etkilenen işyeri mutluluğu kavramı aynı zamanda birçok tutum ve davranışı da etkileyerek önemli çıktılara neden olmaktadır. Bu bağlamda iş yeri mutluluğu; genel hayat mutluluğu, işe bağl1lık, yüksek motivasyon (Jones, 2010), yaratıcılık (Achor, 2010), yüksek performans (Wright ve Cropanzano, 2004; Hosie vd, 2012), devamsızlık (Alves vd., 2012) ve prososyal iş davranışı (Alpaslan, 2015) gibi hem bireysel hem de örgütsel olumlu çıktılara neden olabilmektedir. 


\section{YÖNTEM}

\subsection{Araştırmanın Amacı}

Araştırmanın amacı; çalışanların işyerlerinde mutlu olmalarını sağlayan faktörleri belirleyerek işyeri mutluluğunun sonuçlarını tespit etmektir. Belirlenen amaç doğrultusunda, araştırmanın temelini aşağıda yer alan sorulara cevap aranması oluşturmaktadir:

1. İşyerinizde mutlu olmanızı sağlayan davranışlar veya faktörler nelerdir?

2. İşyeri mutluluğunun sonuçlarını anlatır mısınız? veya İşyeri mutluluğu beraberinde neyi getirir?

\subsection{Araştırma Deseni}

Bir araştırmadaki amaç ve sorular hangi araştırma deseninin kullanılması gerektiğini belirleyen önemli faktörler arasında yer almaktadır (Yılmaz ve Şahin, 2016: 142). Bu nedenle bu çalışmada, araştırmanın amacına ve sorularına uygun olan nitel araştırma desenlerinden "fenomenoloji" kullanılmıştır. Fenomenolojik araştırma, gündelik yaşamda farkında olduğumuz ancak detaylı ve derinlemesine bir düşünceye sahip olmadığımız olgulara yoğunlaşarak (Yıldırım ve Şimsek, 2018: 69), deneyimlerimizi ve bu deneyimlere yüklediğimiz anlamı açığa çıkarmayı hedeflemektedir (Titchen ve Hobson, 2005: 123). Bu kapsamda çalışmada "işyeri mutluluğu" fenomen olarak ele alınmış ve katılımcıların birbirinden farklı deneyimlerinden faydalanarak işyeri mutluluğunun öncülleri ve sonuçları üzerine odaklanılmıştır.

\subsection{Kat1lımcilar}

Fenomenolojik araştırmalarda veriler, araştırma kapsamında odaklanılan fenomeni bizzat deneyimleyen ve deneyimlerini açıkça ifade edebilen kişi veya gruplardan elde edilir (Yıldırım ve Şimşek, 2018: 71). Bu doğrultuda, araştırmada katılımcı seçiminde iki ölçüt esas alınmıştır. Bunlardan ilki; işyeri mutluluğu çok genel ve herkesin alg1 ve deneyimlerinin farklı olabileceği bir fenomen olmasından dolayı katılımcıların özel sektörde (çeşitli kurumlarda) farklı unvanlarda çalışan kişilerden oluşması, diğeri ise bu fenomeni yansıtabilecek durumda olmasıdır. Katılımcılar, amaçlı örnekleme yöntemlerinden biri olan "maksimum çeşitlilik" örneklemesine göre belirlenmiştir. Araştırmada maksimum çeşitlilik örneklemesinin kullanım nedeni ise, farklılık gösteren durumlar arasında ne tarz farklılıkların veya benzerliklerin olduğunu belirlemektir (Punch, 2020: 132). Ayrica araştırmada katılımcı olarak özel sektörde yer alan kişilerin seçilme nedeni, Türkiye'de daha önce bu örnekleme yönelik nitel bir araştırma yapılmamasıdır.

Nitel araştırmalarda örneklem büyüklüğünü belirlemeye yönelik farklı görüşler hâkim olmakla birlikte tartışmalı bir konu olarak değerlendirilmektedir (Marshall, 2013: 11; Yıldırım ve Şimşek, 2018: 124). Çünkü nitel araştırmalarda gerekli örneklem hacmi, kullanılan yönteme ve araştırma desenine göre farklılık göstermektedir. Örneğin, kuram oluşturma yönteminde 20 ila 30 arasında görüşmeciye ihtiyaç duyulurken; fenomenoloji yönteminde görüşmeci sayısı 6 ila 30 arasında değişmektedir (Cohen vd., 2000: 56; Gentles vd, 2015: 1783). Fenomenoloji yöntemine göre yapılan bu araştırmada ise toplam 10 katılımcı ile görüşme yapılmış ve veri doygunluğuna ulaşıldığı için veri toplama bırakılmıştır. 
Araştırma bulguları sunulurken, katılımcılara ait kimlik bilgilerinin gizli tutulması amacıyla her bir katılımcıya (Katılımcı 1, Katılımcı 2, Katılımc1 3) şeklinde rumuzlar verilmiş ve katılımcılara ait bilgiler Tablo 1'de gösterilmiştir.

Tablo 1. Katılımcilara Ait Bilgiler

\begin{tabular}{|c|c|c|c|c|c|c|}
\hline Katılımcı & Cinsiyet & $\begin{array}{c}\text { Medeni } \\
\text { Durum }\end{array}$ & Yaş & Eğitim & Unvan & $\begin{array}{c}\text { Çalışma } \\
\text { Süresi }\end{array}$ \\
\hline Katılımcı 1 & Kadın & Evli & 34 & Yüksek Lisans & $\begin{array}{c}\text { Finans ve Muhasebe } \\
\text { Sorumlusu }\end{array}$ & 8 yıl \\
\hline Katılımcı 2 & Erkek & Evli & 38 & Ön Lisans & Servis Danışmanı & 6 yıl \\
\hline Katılımcı 3 & Erkek & Bekâr & 29 & Lisans & Yönetici Asistanı & 4 yıl \\
\hline Katılımcı 4 & Erkek & Evli & 41 & Lisans & Satış Danışmanı & 8 yıl \\
\hline Katılımcı 5 & Kadın & Evli & 36 & Lisans & $\begin{array}{c}\text { Çă̆rı Merkezi Müşteri } \\
\text { Temsilcisi }\end{array}$ & 10 yıl \\
\hline Katılımcı 6 & Kadın & Bekâr & 28 & Yüksek Lisans & Mimar & 3 yıl \\
\hline Katılımcı 7 & Erkek & Bekâr & 31 & Lisans & $\begin{array}{c}\text { Müş̧teri Hizmetleri } \\
\text { Temsilcisi }\end{array}$ & 5 yıl \\
\hline Katılımcı 8 & Kadın & Evli & 29 & Lisans & Satış ve Kasa Temsilcisi & 2 yıl \\
\hline Katılımcı 9 & Kadın & Bekâr & 33 & Lisans & Grafik Tasarımc1 & 3 yıl \\
\hline Katılımcı 10 & Erkek & Evli & 36 & Doktora & Bölge Satış Yöneticisi & 5 yıl \\
\hline
\end{tabular}

\subsection{Veri Toplama Arac1}

Araştırmada, veri toplamak amacıyla nitel araştırma teknikleri arasında yer alan yarı yapılandırılmış görüşme yöntemi kullanılmıştır. Görüşme sorularının oluşturulmasına yönelik konuya ilişkin literatür taraması yapılmış ve mevcut alt yapının gözden geçirilmesiyle araştırmacı tarafından görüşme formu hazırlanmıştır. Ardından nitel araştırma konusunda tecrübeli iki akademisyenin görüşlerinden faydalanarak gerekli düzeltme ve düzenlemeler yapılmış ve görüşme formunun nihai hali oluşturulmuştur. Ayrıca esas görüşmelere geçilmeden önce, görüşme formunun son hali pilot uygulama için iki akademisyene yöneltilmiştir. Pilot uygulama sonuçlarına bağlı olarak özellikle bazı kelimelerin değiştirilmesi ve bazı ifadelerin ise sadeleştirilmesi gibi değiş̧iklikler yapılmıştır.

\subsection{Verilerin Toplanması ve Analizi}

Araştırmaya ait veriler, araştırmacı tarafından 22-29 Mart 2021 tarihleri arasında katılımcılarla yüz yüze görüşmeler yapılarak toplanmıştır. Görüşmeler katılımcıların işyerleri ziyaret edilerek gerçekleştirilmiştir. Görüşmelere başlamadan önce katılımcılara çalışma ile ilgi birtakım bilgiler sunulmuş ve görüşme sırasında ses kayıt cihazı kullanılacağ ve isimlerin gizli tutulacağı sözlü olarak belirtilmiştir. Bu kapsamda, görüşmede açı uçlu sorular sorularak hem not alınmış hem de ses kaydı olarak kaydedilmiştir. Ayrıca görüşmelerin soru-cevap şeklinde geçmesinden ziyade sohbet şeklinde gerçekleştirilmesine dikkat edilerek katılımcların yeterince düşünmelerine ve ilgili fenomeni ifade etmelerine olanak sağlanmıştır. Görüşmelerin en kısası 32 dakika, en uzunu ise 38 dakika sürmüştür.

Araştırma için toplanan verilerin analizinde içerik analizi kullanılmıştır. Veriler Yıldırım ve Şimşek (2018: 243)'in belirttiği gibi dört aşamada analiz edilmiştir: i) verilerin kodlanması, ii) 
temalarının bulunması, iii) kodların ve temaların düzenlenmesi ve iv) bulguların tanımlanması ve yorumlanmasi.

\section{BULGULAR}

Araştırmanın bu bölümünde, görüşmeler sonucunda elde edilen verilerin analiz sonuçlarına yer verilmiştir. Sonuçlar araştırmanın amacına uygun olarak "İşyeri Mutluluğunun Öncüllerine İlişkin Bulgular ve İşyeri Mutluluğunun Sonuçlarına İlişkin Bulgular" olmak üzere iki üst tema şeklinde sunulmuştur.

\section{1. İşyeri Mutluluğunun Öncüllerine İlişkin Bulgular}

İşyeri mutluluğunun öncülleri "bireysel faktörler", "yönetici kaynaklı faktörler", "örgütsel faktörler", "iş ile ilgili faktörler" ve "çevresel faktörler" olmak üzere beş tema altında toplanmiştır.

\section{Bireysel Faktörler}

İşyerinde mutlu olmayı sağlayan öncüller arasında bireylerin bazı karakteristik ve demografik özellikleri yer almaktadır. Pozitif kişilik, içtenlik, enerjik, güler yüz, alçakgönüllülük, dürüstlük, azim, iyimserlik, tecrübe, yetenekli ve çalışkan olma, yardımsever, zevk alma, muhakeme gücü, özgüven, uyum ve şükran duyma ya da maneviyat gibi bireye ait karakteristik özelliklerin yanı sıra gelir gibi demografik değişken de işyeri mutluluğunun öncülleri arasında yer almaktadır. Katılımcıların bu temaya ilişkin ifadeleri aşağıdaki gibidir:

"Pozitif bir kişiliğe sahip olmam, beni mutsuz eden şeylere takılmak yerine hayattan keyif almaya yönlendirir. Bu durum işyerimde de geçerlidir ve işte mutluluk nedenimdir. Ayrica arkadaş canlısı, enerjik, güler yüzlü, dürüst ve tecrübeli olmam işyerimdeki ilişkilerime yansıyor ve bu durum beni mutlu ediyor." (Katılımo 1); "Uyumlu ve sağliklı olmam (hem fizyolojik hem de psikolojik) beni işyerim dâhil her ortamda mutlu ediyor. Ayrıca aldı̆̆ım maaşın tatmin edici nitelikte olmasını da unutmamak gerekir." (Katılımcı 3); "Azimli, kararlı, çalışkan, yetenekli ve alçakgönüllü olmam beni işyerimde mutlu eden özelliklerimdir." (Katılımcı 4); "Güne sahip olduklarıma şükrederek başlamam ise işte daha çok mutlu olmamı sağlıyor." (Katılımcı 5); "Să̆glklı olmam ve pozitif psikolojik güdülerimin (iyimser, umutlu, dayanıklı) olması iş yaşamında beni her daim mutlu ediyor. Ayrıca bir kadın olarak tek başıma ayaklarımın üstünde duruyor olmanın verdiği hazzı atlamamak gerekir. Arkadaş canlısı bir insanım bu iş ortamında da böyle. Elimden geldiğince iş arkadaşlarımın sıkıntılarını dinleyip onlara çok az da olsa destek olabiliyor olmam yani onların hayatına dokunuyor olmam mutluluk sebebi." (Katılımo 6); “.. Bu arada maaş+prim usulü bir ücretlendirme yapısının olması da her aybaşı farklı bir mutluluk." (Katılımcı 7); "Pozitif ve umut dolu bir kişiliğim olduğu için bu özelliğim iş ortamına yansıyor ve beni mutlu ediyor." (Katılımcı 8); "Yaşamdan zevk almam, muhakeme gücüne sahip olmam, kendime güvenmem, çalışkan, yardımsever ve uyumlu olmam, gelirimin yaşam standartlarının üstünde olması."(Katılımcl 9); "Sağglıklı olmam ve her yeni güne sağllkla uyanmanın verdiği bilincin iş yerime mutluluk olarak yansıması. Bu arada insanları özel ve iş yaşamlarında mutluluklarmı engelleyen şeyin şükretmeyi unuttukları olduğu kanısındayım. Sonuç olarak, şükür işyerimde mutlu olmamı sağlayan en önemli faktördür." (Katılımcı 10). 


\section{Yönetici Kaynaklı Faktörler}

Yöneticilerin iletişime açık, adil, dürüst, destekleyici, güvenilir, tecrübeli, yardımsever, içten, hakkaniyetli, bilgili, rahat, anlayışlı, yetenekli, yönlendirici, şeffaf, yenilikçi olması gibi özellikleri ve yönetsel faaliyetlere yönelik bazı tutum ve yaklaşımları çalışanların işte mutlu olmalarını sağlamaktadır. Katılımcıların bu konudaki düşünceleri aşağıdaki gibidir:

"Yöneticim işyerimdeki mutluluğumu etkileyen en önemli unsurdur. Yöneticim ile iletişimimin iyi olması, adil davranması, dürüst olmasl, beni desteklemesi, güven vermesi ve tecrübeli olması mutlu olmam için yeterli değil mi sizce!" (Katılımo 2); "Patronumun aynı zamanda yöneticimin yardımsever, içten, güvenilir, hakkaniyetli ve donanımlı yapı da olması." (Katılımcı 3); "Müdürüme gelince çok fazla otorite kurmaması beni kendi halime bırakması yani iş özerkliğimin olması işteki diğer bir mutluluk sebebimdir." (Katılımoı 4); "Müdürümün anlayışl, yetenekli, adil, yardımsever ve yönlendirici olması da işyerimde mutlu olmamı önemli ölçüde etkilemektedir. Çünkü bu yapıda olması özgüvenimi arttırıyor ve işimi severek yapmamı sağlıyor." (Katılımcı 7); "Anlayış, adalet, destek, güven, şeffaflık ve liyakat iş yaşamı mutluluğunda önemli şeylerdir. Çünkü bu tutum ve davranışlar ortamda huzur yaratıyor ve insanı motive ederek işe bağhllı̆̆ artırıyor. İs te yöneticim bunları sağlıyor ve ekibini mutlu ediyor." (Katılımcı 9); "Müdürümün dürüst, güvenilir, yenilikçi, bilgili, donanıml olması, beni ve diğer çalışanları desteklemesi büyük bir heyecanla çalışmamı sağhlyor ve mutlu oluyorum." (Katılımcı 10).

\section{Örgütsel Faktörler}

Örgütsel faktörler, çalışanların işyeri mutluluğunda kilit rol oynamaktadır. İşyeri arkadaşlığı, örgütsel iletişim, örgütsel güven, katılımcı yönetim anlayışı, örgütsel destek, adil-şeffaf ve anlayışlı yönetim yapısı, esnek çalışma saatleri, cazip iş ve çalışma koşulları veya şartları, ödüllendirmelerin olması, örgüt içinde değerli görülme, özerklik, bireylerin kendini geliştirebilecekleri çalışma ortamı, kariyer yönetimi, örgütsel adalet, yenilikçiliği ve yaratıcılığ1 destekleyen örgüt kültürü, kişi-örgüt uyumu, sosyal ilişkiler ve kurumsallık gibi birçok örgütsel faktörün işyeri mutluluğunun öncülleri arasında yer aldığı belirtilmiştir. Katılımcıların örgütsel faktörlere ilişkin ifadeleri ise aşağıda sunulmuştur:

"Mesai arkadaşlarımla olan iletişimim ve onlara duyduğum güven, iş ile ilgili konularda kararlara katılabiliyor olmam ve en önemlisi işimde kişisel düşüncelerimi rahatlıkla dile getirmem işimde mutlu olmamı sağlıyor. Ayrıca üst yönetim ile iletişimimin ve ilişkilerimin iyi olması ve sürekli destek görmem." (Katılımo 1); Şirketin çalışma koşullarının iyi olması (katı mesai kurallarının olmaması, maaşın tatmin edici olması, maaş harici araba, yakıt ve yemek kartı gibi desteklerin olması, hafta sonu 2 gün tatilin olması ayrıca resmi günlerde de tatil olmasi), tutarlı politikalar uygulaması ve güven vermesi, yenilikçi oluşu ve çalışanına sahip çıkması sadece benim değil neredeyse bünyesindeki bütün personelin mutlu olmasını sağlıyor. Diğer bir unsur çalışma arkadaşlarımdır. İşyeri arkadaşlığından ziyade kurulan dostluğumuzun iş haricinde de devam etmesi beni işyerimde mutlu ediyor." (Katılımor 2); "Herkesçe bilinen bir şirkette çalışıyor olmam ve bunun bana getirdiği prestij, etkin bir örgütsel iletişim ağının ve desteğinin olması huzurun ve mutluluğun kendisidir kanısındayım." (Katılımoı 3); Çalışma saatlerimin esnek olması, işimle ilgili özerk kararlar alı inisiyatif kullanmam ve şirketimde kariyer yönetimi uygulamalarna yer verilmesi beni oldukça mutlu ediyor." (Katılımcı 4); Yönetim her ne kadar katı kurallar veya prosedürler 
uygulasa da bu çok fazla mutsuz olmamı sağlamıyor. Çünkü bunu eşitlik çerçevesinde yapıyorlar. Şirketin koyduğu hedeflere ulaştığımda yönetim tarafindan değer görmem ve takdir edilmem ise diğer bir mutluluk sebebidir. Çünkü başka şirketlerde çalışan arkadaşlarımın başarıları hep görmezden geliniyor ve hep şikâyetçi ve mutsuzlar bu duruma bağlı olarak motivasyonları ve performansları düşüyor ve kuruma bağlllıkları azalıyor. Çalıştığım kurumun kişisel gelişim ve yükselme imkânı sağlaması da ayr bir mutluluktur." (Katılımo 5); "Çalışma ortamının ahengi, yönetimin anlayışl ve adil bir yapıya sahip olması ve çalışanların desteklemesi, çalışma arkadaşlarım ve yönetim ile kurmuş olduğum iyi ilişkiler, çeşitli ödüllendirmelerin yapılması, yaratıcılı̆̆ı destekleyen kültürün olması, beni işte daha çok mutlu ediyor." (Katılımcı 6); İnsanlarla kurmuş olduğum iletişim ve buna bağh olarak ortaya çıkan ilişkiler benim için hep önemli olmuştur. Bu nedenle çalıştığım yerde yönetim, müdürüm ve iş arkadaşlarımla yakaladığım uyum ve olumlu ilişkiler beni çok mutlu ediyor." (Katılımcı 7); Yönetimin şeffaf ve adil olması, karar alımların da düşüncelerimi önemsemesi ve çalışma ortamının huzuru mutlu olmamda etkilidir."(Katılımoı 8); İşimde kendimi geliştirebilmem için gerekli imkânların sağlanması ve işyeri tarafindan desteklenmem, değerli görülmem, ekip arkadaşlarımın dinamik, yaratıcı ve yeniliğe açık olması, patronun işle ilgili her konuda özgürce davranmamıza izin vermesi, işyeri ile ilgili alınacak kararlarda düşüncelerimin benimsenmesi." (Katılımcı 9); İsyeri arkadaşlığı, adil yönetim yapısı, esnek çalışma saatleri, hafta sonları çalışmama, şirket tarafindan hem kariyer hem de kişisel gelişim için sürekli eğitimlerin verilmesi, küresel ve kurumsal bir şirkette çalışıyor olmamın vermiş olduğu haklı gurur." (Katılımo 10).

\section{İş İle İlgili Faktörler}

Çalışanların işe karşı geliştirdikleri tutumlar ve işin nitelikleri işyeri mutluluğunun belirleyicisi olarak karşımıza çıkmaktadır. İşi sevme, kişi-iş uyumu, işin kariyer fırsatı sunması, nitelikli, anlamlı, çekici, zorlayıcı, dinamik, gelişime ve yeniliğe açık olması, rutin olmaması, işe duyulan bağl1lık ve istek, çalışanın iş üzerinde denetime ve özerkliğe sahip olması gibi iş ile ilgili faktörler işyeri mutluluğunun öncülleri arasında yer almaktadır. Katılımcıların bu temaya yönelik ifadeleri aşağıdaki gibidir:

"İşimi sevmem, işimle uyumlu olmam ve işimin kariyer yapmaya uygun olması benim için mutluluk kaynă̆ıdır." (Katılımcı 3); "İşimin nitelikli ve anlamlı olması, işe karşı olan bağlılığım ve isteğim, işimle ilgili özerk kararlar alıp inisiyatif kullanmam." (Katılımcı 4); "Bence işini seven herkes her koşulda mutlu olur." (Katılımoı 5); İşimin anlamlı olması ve keyifle yapıyor olmam, işin çekici ve gelişime açık olması ve işimle uyum içinde olmam işteyken beni iyi hissettiriyor." (Katılımoı 9); "İşimi ve sektörü sevmem, iş üzerinde denetime ve özerkliğe sahip olmam, işteki dinamizm ve zorluk, işimin sürekli yenilik gerektirmesi, rutin olmaması ve terfiye uygun olması işime ve şirketime olan bağ̆ılı̆̆ımı arttırıyor ve beraberinde mutluluğu getiriyor." (Katılımcı 10).

\section{Çevresel Faktörler}

Yukarıda belirtilen bireysel, yönetici kaynaklı, örgütsel ve iş ile ilgili faktörler haricinde aile, müşteri ve sosyal çevre gibi çevresel faktörler de işyeri mutluluğunun öncülleri arasında yer almaktadır. Katılımcıların çevresel faktörlere yönelik ifadeleri aşağıda sunulmuştur:

"İş dışındaki yaşamımda ilişkilerimin iyi olması ve toplumdaki statü beni mutlu ediyor." (Katılımoı 1);".. Bu arada laf aramızda evdeki huzur işyerinde mutlu olmanın altın kural." 
(Katılımcı 2); "Mesai saatleri haricinde de müşterilerimle sürekli iletişim halinde olmak beni mutlu ediyor." (Katılımo 4); "Bu hayatta beni en çok mutlu eden şey ailemdir. Aile içerisindeki yaşanan herhangi bir olumsuzluk direk işime yansir ve işimde mutsuz olurum. Dolayısıyla ailedeki mutluluk=işteki mutluluktur."(Katılımo 8); "Sosyal çevremin geniş olması ve bu durumun destek şeklinde yani iş olarak işyerime yansıması diyebilirim." (Katılımcı 9). "Kaliteli ve donanımlı müşterilere sahip olmak ve onlarla iş dışında da görüşmek beni hem geliştiriyor hem de mutlu ediyor. Ayrica huzurlu bir aileye sahip olmak işyeri mutluluğu için kilit bir unsur" (Katılımoı 10).

\section{2. İşyeri Mutluluğunun Sonuçlarına İlişkin Bulgular}

İşyeri mutluluğunun sonuçları "örgütsel sonuçlar" ve bireysel sonuçlar" olmak üzere iki tema altında toplanmıştır.

\section{Örgütsel Sonuçlar}

İşyeri mutluluğunun örgütsel sonuçları, yüksek iş performansı, daha etkili ve verimli çalışma, daha fazla çalışma ve en iyisini yapma isteği, güler yüz, olumlu etkileşim, iş yapma hevesi, işe adanma, örgütsel özdeşleşme, çalışmak için yüksek motivasyon, iş tatmini, işe odaklanma, müşteri memnuniyeti ve daha fazla satış, yüksek enerji, sabır, örgütsel bağl1lık, örgütsel başarı, prososyal örgütsel davranış ve kârlılıktır. Katılımcıların bu temaya yönelik ifadeleri aşağıdaki gibidir:

"İ̧̧ ile ilgili süreçleri hızlı bir şekilde tamamlarım. Mesela 3 saatte yazılacak bir raporu 2 saatte yazabilme gibi. Bu durum ayrıca işimi doğru bir şekilde tamamlamamı da sağlar. Tabii bu işlerimi bitirdikten sonra kaytarmam anlamına gelmiyor. Mutluysam daha fazla çalışmak için çabalarım. Yapılacak işim olmasa bile işte en iyisini yapabilmek için kafa yorarım." (Katılımoı 1); İşte mutlu olduğumda yüzüm hep güler bu da çalışma arkadaşlarıma yansır. Aynı şekilde çalışma arkadaşlarımın da işteyken mutlu olması beni pozitif etkiliyor ve işimizi şevkle yapıyoruz. Ayrıca işe ilişkin tüm süreçleri gerektiği gibi yerine getirmeye çalışırım. Sonuç olarak burada olmaktan mutluyum ve asla işten ayrilma niyetim yok." (Katılımor 2); "İşime ve işyerime fazlasıla aidiyetlik hissetmemi sağhlyor. İşyerinde mutluysam genellikle motivasyonum da yüksek oluyor ve yaptığım işten keyif alıyorum. Bu da ay sonunda yüksek iş performansı şeklinde sonuçlanıyor. Bu durumda hem ben mutlu oluyorum hem de yönetim mutlu oluyor ve karşılıklı kazanıyoruz (win-win)." (Katılımò 3); "İşime daha fazla odaklanıyorum ve işimi şevkle yapıyorum bu da haliyle müşterilerime yansıyor ve daha çok satış yapıyorum." (Katılımo 4); "İsyerinde mutlu olduğum zaman kendimi daha enerjik hissediyorum ve işime daha rahat odaklanıyorum. Mutluluğum iş arkadaşlarıma ve müş̧erilerime olan davranışlarımı daha sabırlı kılıyor." (Katılımcı 5); "İşyerinde mutlu olmam, işime ve çalıştı̆̆ım kuruma karşı daha fazla bağlllık hissetmemi sağlıyor ve performansımı arttırıyor." (Katılımo 6)"; Işsimde mutlu olduğumda, işime, müdürüme ve çalıştı̆̆ım yere karşı daha sadık hale geliyorum." (Katılımcı 7); "Başarı, yüksek performans, müşteri memnuniyeti, kurum için daha fazla çalışma isteği şeklinde sıralamam mümkün." (Katılımcı 8); "İşte mutlu olduğum zaman çalışma arkadaşlarıma daha çok yardım ediyorum, daha çok çalışıyorum, işimi daha fazla özümsüyorum ve müşteri memnuniyeti için ziyaretlerde bulunuyorum." (Katılımcı 9); "Kısaca mutlu çalışan= yüksek kârlı şirkettir." (Katılima 10). 


\section{Bireysel Sonuçlar}

İşyeri mutluluğunun bireysel sonuçları arasında aile mutluluğu ve huzuru, öznel iyi oluş, yüksek motivasyon, umut, genel hayat mutluluğu, huzur, özgüven, gelişme isteği, olumlu sosyal ilişkiler, yaşamı anlamlı kılma, yaşam tatmini ve yardımlaşma gibi konular yer almaktadır. Katılımcıların bu temaya yönelik ifadeleri ise aşağıdaki gibidir:

"Evdeki huzur nasıl işe yansıyorsa işteki mutlulukta aileme yansıyor. Yani işteki mutluluğum özel hayatımı derinden etkiliyor." (Katılımcı 1); "Psikolojik olarak kendimi daha iyi hissediyorum. Bu da sosyal hayatımda dışa dönük ve optimistik olmamı să̆lıyor" (Katılımcı

2); "Motivasyonum yüksek oluyor, sosyal çevreme keyifli bir şekilde daha çok zaman ayırıyorum ve geleceğe umutla bakmamı să̆lıyor."(Katılım 4); "Genel hayat mutluluğum üzerinde etkisi çok fazla diyebilirim."(Katılımcı 5); "Hayata pozitif bakmama neden oluyor ve çalışmadığım günlerde kafam daha rahat oluyor yani huzurlu oluyorum. Ancak iş yerimde mutsuz bir gün ya da hafta geçirdiysem ister istemez işte olmadiğım zamanlarda modum düşüyor." (Katılımcı 6); "Özgüvenimi arttırıyor, kendimi sürekli geliştirmek istiyorum ve özel hayatıma olumlu etkisi oluyor." (Katılımon 7); "Sosyal ilişkilerimin daha iyi olmasın sağhıyor ve hayatı daha anlamlı kılıyor." (Katılımo 8); "İşteki mutluluk beraberinde özgüven, yaşam keyfi ve yardımlaşma duygularını getirmektedir." (Katılımoı 9).

\section{SONUÇ VE DEĞERLENDİRME}

Çalışmak zorunda olan ya da çalışmayı tercih eden insanların vaktinin çoğu iş ortamında geçmekte ve iş hayatında mutlu olmaları hem genel yaşam doyumlarını hem de örgütlerin etkinliğini ve verimliliğini etkilemektedir. Bu sebeple, iş yaşamında bireylerin mutlu olmalarını sağlayan faktörlerin neler olduğunu anlamak ve mutluluğun sonuçlarını belirlemek önemlidir. İşyeri mutluluğunun birçok öncülü ve sonucu olduğu düşünülerek bu faktörleri belirlemek ve sinıflandırmak amacıyla yapılan bu çalışmada, her biri farklı kurumda çalışan 10 katılımcının deneyimlerinden faydalanarak işyeri mutluluğunun öncülleri ve sonuçları yarı yapılandırılmış görüşmelerle incelenmeye ve yorumlanmaya çalışılmıştır.

Araştırmaya katılanların demografik bilgileri incelendiğinde, katılımcıların cinsiyetlerinin, medeni durumlarının, yaşlarının, eğitim seviyelerinin, çalışmış oldukları birimlerin ve çalışma yıllarının farklılık gösterdiği görülmektedir. Katılımcılara ait bu farklılık, demografik özelliklerin işyeri mutluluğu üzerinde etkisinin olup olmadığına dair çıkarım yapılmasına imkân sağlamaktadır. Bu doğrultuda katılımcıların demografik bilgilerine ve işyeri mutluluğu ile ilgili ifadelerine bakıldığında, söylemlerin birbiriyle benzer olduğu görülmektedir. Dolayısıyla söz konusu demografik özelliklerin işyeri mutluluğu üzerinde önemli etkilerinin olmadığını söylemek mümkündür. Ancak demografik özelliklerin işyeri mutluluğu üzerindeki etkisine yönelik net bilgilerin verilebilmesi için nicel analizlerin yapılması gerekmektedir.

Araştırma bulgularına göre, işyeri mutluluğunun öncülleri; "Bireysel Faktörler", "Yönetici Kaynaklı Faktörler", "Örgütsel Faktörler", "İş ile İlgili Faktörler" ve "Çevresel Faktörler" olmak üzere beş üst temaya ayrılmıştır. Bireysel faktörler, çalışanların karakteristik ve demografik özellikleri şeklinde ortaya çıkmaktadır. Karakteristik özelliklere ilişkin pozitif kişilik, içtenlik, güler yüz, alçakgönüllülük, dürüstlük, azim, iyimserlik, tecrübe, yetenekli ve 
çalışkan olma, yardımsever, zevk alma, muhakeme gücü, özgüven, uyum ve şükran duyma ya da maneviyat gibi bulgulara rastlanmıştır. Bu durumda, bireylerin sahip olduğu pozitif psikolojik sermaye ve beşeri sermayeleri ile işyeri mutluluğu arasında pozitif bir ilişkinin olduğunu söylemek mümkündür. Demografik değişkenler arasında yer alan gelirin, işyeri mutluluğu üzerindeki etkisini göz ardı etmemek gerekir. Çünkü insanların çalışmalarındaki temel amacin, ihtiyaç ve gereksinimlerini karşılayabilmek için gelir elde etmek olduğu dikkate alındığında gelire dayalı beklentilerinin karşılanması durumunda mutlu oldukları aşikârdır. Nitekim araştırma kapsamında yapılan görüşmelerde de, gelirin işyeri mutluluğundaki önemi vurgulanmıştır. Karakteristik özellikler ve gelirin yanı sıra bireylerin fiziksel ve psikolojik sağlık durumlarının iyi olması da işyeri mutluluğunun diğer bir öncülü olarak karşımıza çıkmaktadır.

İşyeri mutluluğunda yönetici kaynaklı faktörler, yöneticinin karakteristik özellikleri, tutumu ve davranışları şeklinde ortaya çıkmaktadır. Görüşmelerden elde edilen bulgulara göre; yöneticilerin iletişime açık, adil, dürüst, destekleyici, güvenilir, tecrübeli, yardımsever, içten, hakkaniyetli, bilgili, rahat, anlayışlı, yetenekli, yönlendirici, şeffaf, yenilikçi olması ve yönetsel faaliyetlere yönelik tutum ve yaklaşımları çalışanların işte mutlu olmalarını sağlamaktadır. Bu noktada, işyeri mutluluğunda yöneticilerin tutumu, davranışları ve karakteristik özellikleri önem arz etmektedir (Januwarsono, 2015; Williams vd. 2017; Salas-Valina ve Alegre, 2018). Örgütsel faktörlere ilişkin her ne kadar birçok öncül belirlenmiş olsa da işyeri arkadaşlı̆̆ı, örgütsel adalet, örgütsel iletişim ve örgütsel desteğin işyeri mutluluğundaki belirleyiciliği daha sık ifade edilmiştir. Dolayısıyla soyut bir kavram olan ve birçok faktörün etkisiyle ortaya çıan işyeri mutluluğunun güçlü bir örgüt ikliminden olumlu bir şekilde etkilendiğini söylemek mümkündür. Bahsi geçen ve belirlenen örgütsel faktörler dışında iş ile ilgili faktörlerde işyeri mutluluğunu sağlama noktasında önemlidir. Çalışanların işe karşı geliştirmiş oldukları olumlu duygular (işini sevme, kişi-iş uyumu, işe bağlılık gibi) ve işin karakteristik özellikleri veya nitelikleri (anlamlı, çekici, dinamik gibi) işyeri mutluluğunun önemli belirleyicileri olarak karşımıza çıkmaktadır. Ayrıca çevresel faktörlere ilişkin sosyal çevrenin geniş olması ve bu çevrenin verdiği destek, aile huzuru ve mutluluğu, toplumdaki statü, çalışanın iş haricinde müşterileri ile kurduğu ilişkiler işyeri mutluluğunda ön plana çıkmıştır.

İşyeri mutluluğunun öncüllerine yönelik elde edilen bulgular, uluslararası yazında yapılan araştırmaların bulgularından genel olarak farklılaşırken; ulusal yazında yapılan araştırmaların bulgularıyla büyük ölçüde benzerlik göstermektedir. Mesela Bane ve Desai (2015), işyeri mutluluğu ile yönetici desteği, maaş, çalışma koşulları, çalışma saatlerindeki esneklik, dinlenme imkânları ve işte tanınma arasında pozitif ilişkilerin olduğu sonucuna ulaşmışlardır. Suojanen (2017), işyerinde kurulan olumlu arkadaşlık ilişkileri, yapılan işte iyi olduğunu hissetme, ödüller, işte akış yaşama, işyeri konumunun ve güzergâhının doğal güzellikler içerisinde yer alması, yaşam veya dünya üzerinde etkisi olan önemli işler yapma, insanlara yardım ederek veya doğru yöne yönlendirerek onlar üzerinde olumlu etkiler yaratma, kimlik ve öz değer oluşturma, yapılan işte ve yaşam üzerinde kontrol sahibi olma gibi faktörlerin işyeri mutluluğuna neden olduğunu ortaya koymuşlarıdır. Alparslan ve arkadaşları (2016), işyeri mutluluğunda iş arkadaşları ile kurulan sosyal ve duygusal bağların ve yine iş arkadaşlarıyla karşılıklı güven ve dayanışma çerçevesinde kurulan sosyal ilişkilerin en önemli etkenler olduğu sonucuna ulaşmışlardır. Güner ve Bozkurt (2017), işyerinde mutlu 
olanların en önemli mutluluk nedenlerini; işyeri arkadaşlı̆̆ı, yapılan işin kendisi, yönetici iletişimi, olumlu çalışma koşulları, ödül ve takdir, müşteri ilişkileri ve hedeflere ulaşmak olarak tespit etmişlerdir. Çakır (2019) ise; iş arkadaşlığ1 ilişkileri, örgütsel adalet, örgütsel iletişim algısı, değer/takdir görme, başarı, ekip çalışması, işin anlamı, fiziksel imkânlar, işle özdeşleşme, işini sevme, nezaket, yönetici/lider desteği, etkileşim ve güven gibi faktörlerin işyeri mutluluğunun öncülleri olduğu sonucuna ulaşmıştır. Bu bağlamda, ulusal ve uluslararası yazında ortaya çıkan bu durumun nedeninin kültürel farklılıklar olduğu düşünülmektedir. Nitekim Wesarat ve arkadaşları (2015) yaptıkları çalışmada, çalışan mutluluğunun kültürel bağlamlarda farklılık gösterebileceğini belirtmişlerdir.

Araştırmadan elde edilen diğer bulgu işyeri mutluluğunun sonuçları ile ilgilidir. Burada işyeri mutluluğunun sonuçları; "Örgütsel Sonuçlar" ve "Bireysel Sonuçlar" olmak üzere 2 üst tema şeklinde değerlendirilmiştir. Örgütsel sonuçlar arasında, yüksek iş performansı, etkili ve verimli çalışma, örgütsel etkileşim, örgütsel özdeşleşme, motivasyon, iş tatmini, işe odaklanma, müşteri memnuniyeti, örgütsel bağlılık, örgütsel başarı ve prososyal örgütsel davranış gibi önemli tespitler bulunmuştur. Bu bağlamda iş yeri mutluluğu çalışanların kurumlarına karşı olumlu duygular geliştirmesine katkı sağlarken, işletmelerin temel hedefi olan yüksek performans ve diğer örgütsel hedefleri gerçekleştirmek şeklinde sonuçlanmaktadır. Bireysel sonuçlara yönelik ise aileye, sosyal ilişkilere ve genel mutluluğa yansıması gibi önemli bulgulara ulaşılmıştır. Her ne kadar günümüz yoğun iş temposuna bağlı olarak bireylerin zamanının çoğu işte geçse de iş dışında ailesi, arkadaşları ve dostları ile de vakit geçirmektedirler. Dolayısıyla iş ortamında yaşanan herhangi bir olumsuzluğun veya mutluluğun istem dişı iş haricindeki çevresine de yansıtmasının doğal olduğu düşünülmektedir. Ayrıca bireysel sonuçlara ilişkin diğer bulgular ise işyerinde mutlu olan katılımcıların daha iyimser, yardımsever ve özgüvenli olduğu yönündedir. Bu durumda bireylerin işyeri mutluluklarının aile ve sosyal yaşamları üzerine önemli etkilerinin olduğunu söylemek mümkündür. İşyeri mutluluğunun örgütsel ve bireysel sonuçlarına yönelik elde edilen bulgular alan yazındaki çalışmaların sonuçlarıyla genel olarak desteklenmektedir (Jones, 2010; Wright ve Cropanzano, 2004; Lyubomirsky vd., 2005; Hosie vd, 2012; Alparslan, 2016; Çakır, 2019).

Çalışmanın nitel araştırma yöntemiyle yapılması, fenomenin çeşitli yönlerden detaylı bir şekilde incelenmesini sağlamıştır. Bu çalışmadan elde edilen sonuçların ileride nicel yöntemle yapılması planlanan araştırmaların kurgulanmasına kaynak sağlayacağı düşünülmektedir. Bu şekilde elde edilen sonuçların, nicel araştırmalarla test edilmesinin daha spesifik sonuçlar sunması beklenmektedir.

Her çalışmada olduğu gibi bu çalışmanın da sınırlılığı bulunmaktadır. Araştırma yalnızca özel sektörde ve herhangi bir alan belirlenmeden yapılmıştır. Bu nedenle ileride sektör ve meslek ayrımları kapsamında farklı sayıda katılımcılarla, farklı yöntemler seçilerek araştırmalar yapılabilir. Böylece konu ile ilgili daha çok bilgi elde edinilecek, sektörler arası karşılaştırma imkânı olacak ve ilgili yazına katkı sağlanacaktır.

\section{KAYNAKÇA}

Achor, S. (2010). The Happiness Advantage: The Seven Principles of Positive Psychology that Fuel Success and Performance at Work, Random House. 
Akın, O. ve Aktar, A. (2019). Muhasebe Meslek Mensuplarında Mesleki Yabancılaşmanın İşyeri Mutluluğu Üzerine Etkisi: Burdur İli Ve Bucak İlçesinde Bir Araştırma. Uluslararası İktisadi ve İdari Bilimler Dergisi, 5(2), 1-24.

Alparslan, A. M. (2016). Emek İşçilerinde Fazladan Rol Davranışının Öncülü: İş Tatmini mi İşyerinde Mutluluk mu?, Atatürk Üniversitesi İktisadi ve İdari Bilimler Dergisi, 30 (1), 201-213.

Alparslan, A. M., Kahraman, M. ve Cantürk, N. (2016). Araştırma Görevlilerinin İşyerinde Mutluluk ve Mutsuzluk Nedenleri: Bir Alan Çalışması, 15. Ulusal İşletmecilik Kongresi Bildiriler Kitapçı̆̆̆

Alves, P. C., Neves, V. F., Coleta, M. F. D., \& Oliveira, A. F. (2012). Evaluation of Well-being at Work Among Nursing Professionals at a University Hospital. Latino-Am. Enfermagem, 20(4), 701-709.

Andrew, S. S. (2011). S.M.I.L.E.S.: The Differentiating Quotient for Happiness at Work. Social Sciences and Medicine, 1-13.

Arslan, Y. ve Polat, S. (2017). Adaptation of Well-Being Work Scale to Turkish. Kuram ve Uygulamada Ĕ̈itim Yönetimi, 23(4), 603-622.

Bane, M. \& Desai, P. (2015). An Empirical Study on Relationship of Various Factors with Workplace Happiness. Reflections-Journal of Management, 3, 1-11.

Cohen, M. Z., Kahn, D. L., \& Steeves, D. L. (2000). Hermeneutic Phenomenological Research: A Practical Guide For Nurse Researchers. Thousand Oaks. CA: Sage Publish.

Çakır, A. A. (2019). Öncülleri ve Sonuçları Bağlamında Akademisyenlerde İş Yeri Mutluluğu: Bir Model Denemesi, Yayınlanmamış Doktora Tezi, Ondokuz Mayıs Üniversitesi Sosyal Bilimler Enstitüsü, Samsun.

Diener, E. (2000). Subjective Well-Being: The Science of Happiness and a Proposal for a National Index. American Psychologist, 55(1), 34-43.

Diener, E. \& Ryan, K. (2009). Subjective Well-Being: A General Overview. South African Journal of Psychology, 39(4), 391-406.

Fisher, C. D. (2010). Happiness at Work. International Journal of Management Reviews, 12(4), 384-412.

Gavin, J. H. \& Mason, R. O. (2004). The Virtuous Organization: The Value of Happiness in the Workplace. Organizational Dynamics, 33(4), 379-392.

Gentles, S. J., Charles, C., Ploeg, J., \& McKibbon, K. A. (2015). Sampling in Qualitative Research: Insights from an Overview of The Methods Literature. The Qualitative Report, 20(11), 1772-1789.

Gilman, R., Huebner, E. S., \& Laughlin, J. E. (2000). A First Study of the Multidimensional Students' Life Satisfaction Scale with Adolescents. Social Indicators Research, 52(2),135160. 
Güner, F. ve Bozkurt, Ö. Ç. (2017). Banka Çalışanlarının İşyerinde Mutluluk ve Mutsuzluk Nedenleri Üzerine Keşif Amaçlı Bir Araştırma, Örgütsel Davranış Araştırmaları Dergisi, 2(2), 85-105.

Hosie, P., Willemyns, M., \& Sevastos, P. (2012). The Impact of Happiness on Managers' Contextual and Task Performance, Asia Pacific Journal of Human Resources, 50 (3), 268287.

Jones, J. P. (2010). Happiness at Work: Maximizing Your Psychological Capital For Success. UK: Blackwell Publishing.

Khosrojerdi, Z., Tagharrobi, Z., Sooki, Z., \& Shari, K. (2018). Predictors of Happiness among Iranian Nurses. International Journal of Nursing Sciences, 5, 281-286.

Kjerulf, A. (2015). Sabah 9'dan Akşam 6'ya Happy Hour. İstanbul: Doğan Egmont Yayıncılık.

Kır, A., Kösem, Ü., Akçakanat, T. ve Uzunbacak, H. H. (2020). Öğretmenlerde Şükrün İşyeri Mutluluğuna Etkisinde Cinsiyetin Düzenleyici Rolü. Uluslararası İktisadi ve İdari Bilimler Dergisi, 6 (2), 5-18.

Lyubomirsky, S., Sheldon, K. M., \& Schkade, D. (2005). Pursuing Happiness: The Architecture of Sustainable Change. Review of General Psychology, 9, 111-131.

Maenapothi, R. (2007). Happiness in the Workplace Indicator. Master's Thesis, Human Resource Development, National Institute of Development Administration.

Marshall, B., Cardon, P., Poddar, A., \& Fontenot, R. (2013). Does Sample Size Matter in Qualitative Research?: A Review of Qualitative İnterviews in IS Research. Journal of Computer Information Systems, 54(1), 11-22.

Punch, K. F. (2020). Sosyal Araştırmalara Giriş: Nicel ve Nitel Yaklaşımlar. Ankara: Siyasal Kitabevi.

Salas-Valina. A. \& Alegre, J. (2018). Unselfish Leaders? Understanding the Role of Altruistic Leadership and Organizational Learning on Happiness at Work (HAW). Leadership $\mathcal{E}$ Organizaiton Development Journal, 39 (5), 633-649.

Salzberg, S. (2013). Real Happiness at Work: Meditations for Accomplishment, Achievement, and Peace, Workman Publishing.

Suojanen, I. I. (2017). Young Professionals and the Pursuit of Happiness at Work, Doctoral Dissertation, The University of Edinburgh.

Tadić, M., Bakker, A. B., \& Oerlemans, W. G. M. (2013). Work happiness among teachers: A day reconstruction study on the role of self-concordance. Journal of School Psychology, 51(6), 735-750.

Titchen, A. \& Hobson, D. (2005). Phenomenology. B. Somekh, C. Lewin (Edit.), Research methods in the social sciences (121-130). İngiltere: SAGE Publications.

Turan, N. (2018). Çalışma Mutluluğu: Kavram ve Kapsam. Uludă̆ Journal of Economy and Society / B.U.Ü. İktisadi ve İdari Bilimler Fakültesi Dergisi, 37(1), 169-212. 
Turan, N. (2019). Bir Kamu Üniversitesi Personelinin Çalışma Mutluluğunu Etkileyen Faktörler: Nitel Araştırma Örneği. Journal of Economy Culture and Society, 60, 187-205.

Türk Dil Kurumu. (2011). Ankara: TDK Yayını.

Veenhoven, R. (2009). How Do We Assess How Happy We Are? Tenets, Implications and Tenability of Three Theories, Happiness, Economics and Politics, 45-69.

Wesarat, P. O., Sharif, M. Y., \& Majid, A. H. A. (2015). A Conceptual Framework of Happiness at the Workplace, Asian Social Science, 11 (2), 78-88.

Williams, P., Kern L. M., \& Waters, L. (2017). The Role of Reprocessing of Attitudes in Fostering Employee Work Happiness: An Intervention Study. Frontiers in Psychology, $8,1-12$.

Wright, T. A. \& Cropanzano, R. (2004). The Role of Psychological Well-being on Job Performance. Organizational Dynamics, 33, 338-351.

Yıldırım, A. ve Şimşek, H. (2018). Sosyal Bilimlerde Nitel Araştırma Yöntemleri (11. Baskı). Ankara: Seçkin Yayıncılık.

Yılmaz, K. ve Şahin, T. (2016). Eğitim Fakültelerindeki Araştırma Görevlilerinin Mesleki Deneyimlerinin İncelenmesi: Araştırma Görevlisi Olmanın Anlamına İlişkin Fenomenolojik Bir Çalışma. Marmara Üniversitesi Atatürk Eğitim Fakültesi Eğitim Bilimleri Dergisi, 44, 143-168. 